\title{
AN ASSESSMENT OF INNOVATIVE AND KNOWLEDGE-BASED SERVICES IN THE POLISH FOREIGN TRADE IN 2010-2017
}

\author{
AGNIESZKA MALKOWSKA
}

University of Szczecin, Faculty of Management and Economics of Services, POLAND

e-mail: agnieszka.malkowska@wzieu.pl

RECEIVED
ACCEPTED
JEL
CLASSIFICATION

KEYWORDS

ABSTRACT
10 December 2018

28 December 2018

$\mathrm{F} 14, \mathrm{~F} 40, \mathrm{O} 11, \mathrm{O} 30$

foreign trade, services, innovative and knowledge-based services, economic development

The article discusses the Polish foreign trade in services. Its main focus is on innovative and knowledge-based services. Their exports and imports, as well as their trade balance for the years 2010-2017, are characterized. The aim of the paper is to identify and assess changes in the Polish foreign trade in innovative and knowledgebased services. The study is based on data published by the National Bank of Poland and the Central Statistical Office. For the purposes of this research, simple statistical methods, desk research and graphic methods were used. Between 2010 and 2017 the value of innovative and knowledge-based services in the Polish foreign trade increased significantly. The growth was recorded for: revenue from foreign sales - threefold, expenses for purchases from abroad - more than twofold, and the trade balance - almost sixfold. The results of this study proved that the structure of the major service components analyzed herein changed. IT services and services provided by professional became dominant. On the basis of selected indicators, it was found that the role of innovative and knowledge-based services is growing, which translates positively into the country's economic development.

\section{Introduction}

Foreign trade brings diverse benefits to the state, among them economic, which is reflected in the GDP. The development of this form of economic activity is a crucial developmental factor for many economies, including Poland. It should be stressed that services have been playing an increasingly significant role in foreign trade, and their growth rate increased significantly in the early 21 st century. 
Nowadays, innovation and knowledge-based services are considered to be the main drivers of economic growth. They are a key factor determining the development of modern economies, undoubtedly improving their effectiveness and strengthening their competitiveness. The opportunity to participate in the international trade in such services is another element contributing to the economy of the given country. Hence, any assessment of the significance of foreign trade for individual economies, in this Polish, calls for an analysis of its structure.

The article discusses the Polish foreign trade in services, with the main focus on innovative and knowledgebased services characterized in terms of their exports, imports and trade balance. The study covered the years 2010-2017, whereas the choice of the specific period was determined by the availability of homogeneous statistical data.

The aim of the research was to identify and assess changes in the Polish foreign trade in innovative and knowledge-based services. Also, an attempt was undertaken to assess the significance of such services for the development of Poland's economy. For the purposes of the research, the following hypothesis was formulated: Within the Polish foreign trade in services, the share of innovative and knowledge-based services is growing, which has a positive impact on the country's economic development. The main body of research material was compiled from factual data published by the National Bank of Poland (NBP) and the Central Statistical Office (GUS). Also, Polish and foreign literary sources related to the subject-matter of the research were used. The research methods applied were simple statistical methods (e.g. shares expressed in terms of percentage), desk research, description with elements of deduction, and graphic methods, i.e. tables and figures.

\section{Literature review}

Foreign trade in services is relatively rarely discussed in the source literature. Among the reasons for this are the problems with defining, classifying and "capturing the nature" of services. Consequently, the available public statistics related to this aspect of economy are quite poor. The developmental potential demonstrated by services was first noticed only as late as 1980s.

Clearly, services differ from other forms of economic activity (see Rathmell, 1986, p. 38). Some authors have attempted to explain and assess their international flows. However, the models developed by, for instance, M.V. Deardorff (1985), Melvin (1989) or J.J. Stibora and de A. Vaal (1995) have turned out to be unsatisfactory (Misala, 2005, p. 145). Consequently, no single, general and exhaustive theory of the international exchange of services has been developed by the end of the second decade of the 21st century. Nevertheless, as highlighted by van D. Welsum (2003, pp. 2-4), the source literature contains no contraindications, be it formal or empirical, to applying the known commodity trade theories to trading in services, provided that the distinctive features of services and the data shortages are taken into account.

The positive influence of foreign trade, including trade in services, on the economic development of countries is indisputable (Jones, Kierzkowski, 2018, pp. 233-253; Malkowska, Malkowski, 2018, pp. 111-122). Research also confirms that the significance of services in the process of shaping innovation is increasing (Ewangelista, Sirilli, 1998, pp. 207-215). 


\section{The Polish foreign trade in innovative and knowledge-based services between 2010 and 2017}

According to NBP reports on the international trade in services, innovative and knowledge-based services fall into four groups, namely: 1) telecommunication, IT and information services; 2) research \& development services; 3) services provided by professionals; 4) fees for intellectual property rights. The Polish foreign trade in innovative and knowledge-based services, between 2010 and 2017 was characterized by dynamic growth. The total value of exports of these services grew from PLN 18.9 in 2010 to PLN 57.2 in 2017 (see Figure 1). This means that revenue from foreign sales of these services increased by as much as $303 \%$. As for the value of their imports, it increased from PLN 21.1 to PLN 47.1 within the same period, which was a 223\% growth. In summary, as regards the services concerned in this paper the growth rate of imports was far lower than that of exports.

In the period concerned, except for 2013, the balance of trade in innovative and knowledge-based services demonstrated an upward trend, as it grew almost six times from PLN -2.3 bln to PLN 10.1 bln. It should be noted that each year between 2010 and 2014 the balance of trade was negative. Only in 2015, 2016 and 2017 was any trade surplus observed, which was mainly thanks to the contribution by IT services (see Figure 1). Therefore, this surplus should not be seen as relatively stable. What is important, however, is that the increase resulted mainly from revenue growing much faster than expenses.

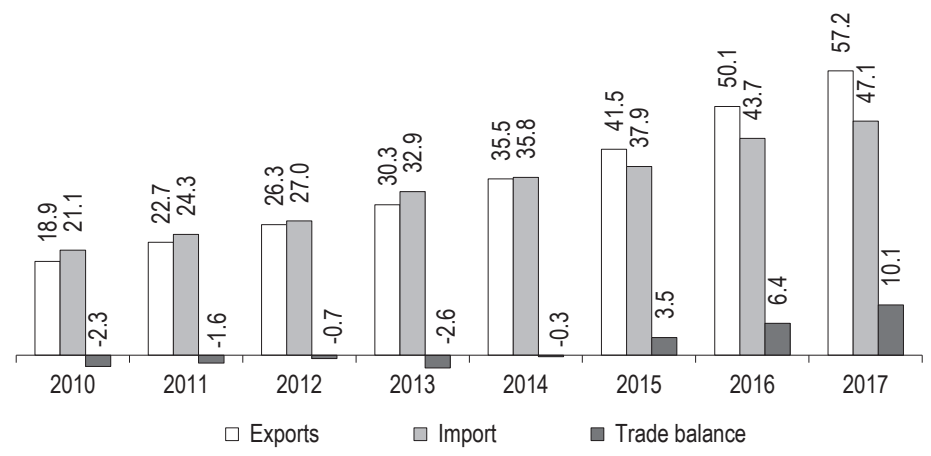

Figure 1. The exports, imports and balance of trade in innovative and knowledge-based services in Poland between 2010 and 2017 (PLN bln)

Source: the author's own study based on the National Bank of Poland (NBP, 2018).

Apart from the overall value of Polish exports and imports of innovative and knowledge-based services, what matters is the structure of these categories, as well (see Table 1). In the period in question, the highest value of exports was achieved by the so-called services provided by professionals, which totaled PLN 10.4 bln. Within this group, the largest share was enjoyed by marketing services, market surveys and public opinion polls (50.9\%), followed by business consultancy and public relations services $(23.1 \%)$. The next largest revenue for the Polish economy was brought by foreign sales of telecommunication, IT and information services (PLN 6.1 bln), where IT services accounted for as much as $68.9 \%$. Between 2010 and 2017 the value of the exports of all the service components considered as innovative and knowledge-based services grew. However, taking into account the value of foreign sales, their place in the ranking stayed the same. 
Tahle 1. Poland's foreign trade turnover by the main components of innovative and knowledge-based services in 2010 and 2017 (PLN bln)

\begin{tabular}{lcccc}
\hline \multirow{2}{*}{ Service } & \multicolumn{2}{c}{2010} & \multicolumn{2}{c}{2017} \\
\cline { 2 - 5 } & exports & imports & exports & imports \\
\hline Telecommunication, IT and information services & 6.1 & 6.6 & 24.0 & 13.7 \\
including: - telecommunication & 1.4 & 1.6 & 2.0 & 2.7 \\
- IT & 4.2 & 4.4 & 20.3 & 9.9 \\
- information & 0.4 & 0.6 & 1.7 & 1.1 \\
\hline Research \& development services & 1.7 & 0.5 & 5.1 & 1.1 \\
\hline Services provided by professionals & 10.4 & 7.3 & 26.0 & 20.4 \\
including: - legal & 0.8 & 0.4 & 1.0 & 0.4 \\
- accounting, auditing and tax consultancy & 1.9 & 0.3 & 7.2 & 1.1 \\
- business consultancy and public relations & 2.4 & 5.1 & 9.3 & 14.0 \\
$\quad$ - marketing, market surveys and public opinion polls & 5.3 & 1.5 & 8.5 & 4.9 \\
\hline Fees for intellectual property rights & 0.7 & 6.8 & 2.2 & 11.9 \\
\hline
\end{tabular}

Source: the author's own study based on: the National Bank of Poland: NBP (2011); NBP (2018).

As for Polish imports of innovative and knowledge-based services, services provided by professionals brought the highest value both in the base year (PLN 7.3 bln) and the target year (PLN 20.4 bln). Out of the main four service components discussed here, the lowest value of expenses was demonstrated by R\&D services in both these years, with PLN 0.1 bln in 2010 and PLN 1.1 bln in 2017.

Telecommunication, IT and information services achieved the highest growth in exports (397\%), followed by fees for intellectual property rights (305\%), R\&D services (299\%) and services provided by professionals (250\%). Within the first of these components, the most spectacular growth (483\%) was demonstrated by IT services. The main contributory elements of this growth were such IT services as consultancy and implementation, technical consultancy related to computer hardware and software, hardware and software installation, and computer and peripheral equipment maintenance and repair (NBP, 2014).

As for of imports, the largest growth was in services provided by professionals $(281 \%)$ and $R \&$ D services $(230 \%)$, and the lowest growth was in fees for intellectual property rights (176\%). For this specific group of services, not only its growth in exports but also in imports should be assessed as a positive factor. The reason for this approach is that importing services allows developing countries or less technologically advanced states to purchase innovative services, receive transfers of new technologies or use specialist knowledge gained from other countries. Occasionally, imports can be the only opportunity for the given country to have access to such services. Undoubtedly, this process can facilitate a positive economic development of the importer, in this case Poland.

\section{An assessment of the significance of innovative and knowledge-hased services for the Polish foreign trade and in the economic development of the country}

One of the simpler indicators for assessing any type of services traded in internationally is the share of such services in total exports and imports. In 2017, innovative and knowledge-based services accounted for one fourth of Polish exports of services and one third of Polish imports of services. Their share in total exports grew by 8.8 percentage points (i.e. from 17.6 to $25.9 \%$ ), and in total imports by 10.1 percentage points (i.e. from 22.5 to $32.6 \%$ ). 
Thus, the share of all four service components analyzed in this paper grew in 2017 as compared to 2010, and this upward trend was observed both in their exports and imports values. The largest increase in foreign sales was observed for the telecommunication, IT and information service component (from 5.7 to 10.9\%), and in purchases made abroad for the component of services provided by professionals (from 7.8 to 14.1\%) (see Table 2).

Table 2. The share of innovative and knowledge-based service components in the Polish foreign trade in services between 2010 and 2017 (\%)

\begin{tabular}{lcccc}
\hline \multirow{2}{*}{ Service } & \multicolumn{2}{c}{2010} & \multicolumn{2}{c}{2017} \\
\cline { 2 - 5 } & exports & imports & exports & imports \\
\hline Telecommunication, IT and information services & 5.7 & 7.1 & 10.9 & 9.5 \\
including: - telecommunication & 1.3 & 1.7 & 0.9 & 1.9 \\
- IT & 4.0 & 4.8 & 9.2 & 6.8 \\
- information & 0.4 & 0.6 & 0.8 & 0.8 \\
\hline Research \& development services & 1.6 & 0.5 & 2.3 & 0.7 \\
\hline Services provided by professionals & 9.7 & 7.8 & 11.8 & 14.1 \\
including: - legal & 0.7 & 0.5 & 0.5 & 0.3 \\
$\quad$ - accounting, auditing and tax consultancy & 1.8 & 0.3 & 3.3 & 0.7 \\
$\quad$ - business consultancy and public relations & 2.3 & 5.4 & 4.2 & 9.7 \\
\hline Fees for intellectual property rights & 4.9 & 1.6 & 3.8 & 3.4 \\
\hline Total & 0.7 & 7.2 & 1.0 & 8.2 \\
\hline
\end{tabular}

Source: the author's own study based on: NBP (2011); NBP (2018).

The ratio of exports and imports to the GDP is one of the basic measures used for assessing the significance of foreign trade for the given country's economy. In the studied period between 2010 and 2017, the rate of exports of innovative and knowledge-based services kept growing systematically - from 1.3 to $2.9 \%$. Similarly, the share of imports in the Polish GDP kept increasing - from 1.3 to $2.4 \%$. This means that, slowly, the Polish economy's openness to trading in these services kept increasing, and its competitiveness was improving. As seen above, the share of exports of services in the GDP grew faster than that of their imports, which should be assessed as a positive trend (see Figure 2).

In making an assessment of the significance of the exchange of services to the country's economy it is relevant to consider the value of exports and imports of innovative and knowledge-based services per capita. For Poland, the this ratio grew by $305 \%$ for exports (i.e. from PLN 0.5 thousand in 2010 to PLN 1.5 thousand in 2017), and by $224 \%$ for imports (i.e. from PLN 0.6 thousand to PLN 1.2 thousand). Therefore, it can be assumed that the human potential was utilized with improved efficiency within the area analyzed herein. It must be remembered that the dynamic growth of the Polish foreign trade was mainly due to contribution from business entities. The number of Polish enterprises exclusively involved in exportation grew between 2010 and 2015 by $31 \%$, to reach almost 41.3 thousand in 2015 (Poniewski, Skóra, 2018, p. 14). The number of enterprises with foreign capital participation increased, as well. The number of those involved in exportation grew from almost 9.5 thousand in 2010 to 11.2 thousand in 2016. Within the same period, the number of enterprises involved in importation increased, too - from over 10.6 thousand to more than 11.9 thousand (GUS, 2011; GUS, 2017). Both exports and imports were dominated in terms of value by companies with foreign capital participation. Normally, such companies find it much easier to access foreign 
markets. They also import intermediate services and know-how. Trade surplus in services is observed both in the transactions carried out by enterprises with foreign capital participation and domestic enterprises. Still, the high positive balance of services was mostly the result of transactions carried out by enterprises with domestic capital (NBP, 2016).

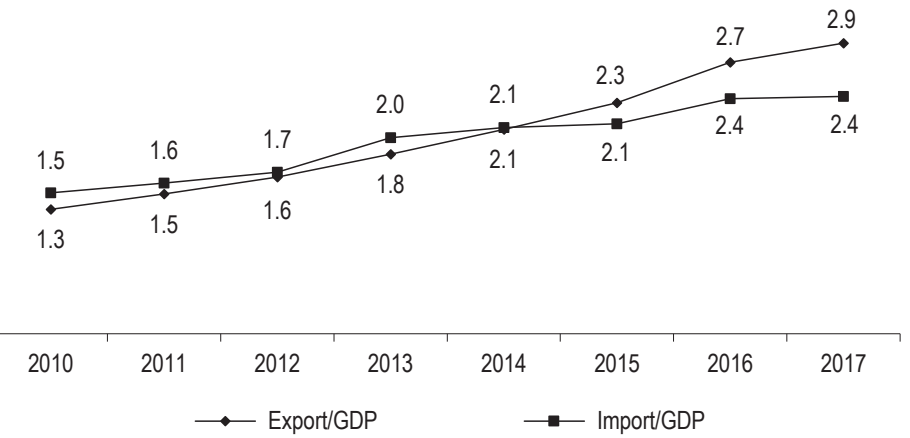

Figure 2. The ratio of the value of innovative and knowledge-based service exports to the Polish GDP (\%) and the ratio of the value of innovative and knowledge-based service imports to the Polish GDP (\%)

Source: the author's own study based on National Bank of Poland (NBP, 2011, 2018); Local Data Bank of the Central Statistical Office (GUS, 2010-2017).

According to the Central Statistical Office, between 2010 and 2012 innovative activity was demonstrated by $13.9 \%$ of Polish service providers, whereas between 2015 and 2017 this figure fell to $11.9 \%$. This drop took place despite service providers having spent $11.7 \%$ more on innovation, corresponding to an increase from PLN 12 bln in 2011 to PLN 13.4 bln in 2017. This might have resulted from the fact that a mere intensification of spending on research and development is insufficient, as structural and institutional changes supporting the development of innovation-based entrepreneurship must be adopted, as well, which is in fact the hard part (Acemoglu, Robinson, 2012). Moreover, one should remember about the new approach to innovation and the observed convergence of the service and the production sectors (Niedzielski, Rychlik, 2007, pp. 177-185).

\section{Conclusions}

Between 2010 and 2017, the Polish foreign trade in innovative and knowledge-based services kept growing dynamically. Their exports and imports increased, and so did their balance of trade, which was positive since 2015. This research showed that the share of innovative and knowledge-based services in the Polish foreign trade is growing, which may be indicative of an increasing level of innovation of the Polish economy.

On the basis of an analysis of the Polish foreign trade in innovative and knowledge-based services, changes in its structure were revealed. Clearly, IT services and services provided by professionals began to be dominant. Thus, a slow transition from traditional services to more modern ones can be observed. However, the low - although growing - share of research and development services is unfavorable.

Between 2010 and 2017, the Polish economy's openness to trading in innovative and knowledge-based services with other countries was growing, as well. The selected indicators confirmed the increasing role of these 
services in Poland's economy. Yet, the dropping innovativeness of Polish service providers is of concern, as it may have a limiting impact on their competitiveness. Removal of these barriers is a challenge that the SME sector and the Polish economic policy-makers must face.

\section{References}

Acemoglu, D., Robinson, J.A. (2012). Why nations fail: the origins of power, prosperity, and poverty. New York:Crown Publishers.

Deardorff, M.V. (1985). Comparative Advantage and Investments in Services. In: R.M. Stern (ed.), Trade and Investment in Services: Canada/US Perspectives (pp. 39-71). Toronto: Ontario Economic Council.

Ewangelista, R., Sirilli, G. (1998). Measuring Innovation in Services. Research Evaluation, 5 (3), 207-215.

GUS (2010-2017). Bank Danych Lokalnych. Retrieved from: https://bdl.stat.gov.pl/BDL/start.

GUS (2011). Działalność gospodarcza podmiotów z kapitałem zagranicznym w roku 2010. Warszawa.

GUS (2014). Działalność innowacyjna w Polsce w 2013 r. Retrieved from: https://stat.gov.pl/obszary-tematyczne/nauka-i-technikaspoleczenstwo-informacyjne/nauka-i-technika/dzialalnosc-innowacyjna-przedsiebiorstw-w-polsce-w-latach-2015-2017,14,5. html.

GUS (2017). Działalność gospodarcza podmiotów z kapitałem zagranicznym w roku 2016. Warszawa.

GUS (2018). Działalność innowacyjna przedsiębiorstw w Polsce w latach 2015-2017. Retrieved from: https://stat.gov.pl/obszarytematyczne/nauka-i-technika-spoleczenstwo-informacyjne/nauka-i-technika/dzialalnosc-innowacyjna-przedsiebiorstw-wpolsce-w-latach-2015-2017,14,5.html.

Jones, R.W., Kierzkowski, H. (2018). The role of services in production and international trade: A theoretical framework. Singapore: World Scientific Publishing Co. Pte. Ltd.

Malkowska, A., Malkowski, A. (2018). Medical tourism as an element of building borderland competitiveness. In: M. Blašková, S. PangsyKania, K. Drela, A. Sokół (eds.), Contemporary issues and economic problems (pp. 111-122). Shaker Verlag, Aachen.

Melvin, M. (1989). Trade in Producer Services: A Heckscher-Ohlin Approach. Journal of Political Economy, 97 (1).

Misala, J. (2005). Wymiana międzynarodowa a gospodarka światowa. Teoria i mechanizmy funkcjonowania. Warszawa: Szkoła Główna Handlowa.

NBP (2010-2018). Międzynarodowy handel usługami. Retrieved from: https://www.nbp.pl/home.aspx?f=/statystyka/mhu.html.

Niedzielski, P., Rychlik, K. (2007). Innowacje w sektorze innowacyjnycm i usługowym - odmienność czy podobieństwo. Zeszyty Naukowe Uniwersytetu Szczecińskiego, 453. Ekonomiczne Problemy Usług, 8, 177-185.

Poniewski, R., Skóra, M. (2018). Handel zagraniczny w Polsce i Małopolsce 2016. Kraków: Urząd Marszałkowski Województwa Małopolskiego.

Rathmell, J.M. (1986). What is meant by services. Journal of Marketing, October, 38.

Stibora, J.J., Val, A., de (1995). Services and Services Trade. A Theoretical Inquiry. Amsterdam: Thesis Publishers.

Welsum, D. van (2003). International Trade in Services: Issues and Concepts. London: Birkbeck College.

Cite this article aS: Malkowska, A. (2018). An assessment of innovative and knowledge-based services in the Polish foreign trade in 2010-2017. European Journal of Service Management, 4 (28/2), 239-245. DOI: 10.18276/ejsm.2018.28/2-30. 